\title{
STUDY ON BEHAVIOUR OF COMPRESSION MEMBER WITH BAMBOO AS REINFORCEMENT And Coconut SHell As Aggregate
}

\author{
A. Joshua Daniel ${ }^{1}$ and S. Sivakamasundari ${ }^{2}$ \\ ${ }^{1,2}$ Department of Civil Engineering, SRM University, Chennai, Tamilnadu, India
}

\begin{abstract}
Concrete is the most widely used construction material. Among all ingredients of concrete, aggregates form the major portion; further there exists a challenge in attaining the structural light weight concrete utilizing the waste. Among the natural waste coconut shells can suitably replace these natural aggregates. The compression testing on cube and split tensile test on cylinder were performed to authenticate its feasibility. Concrete is reinforced with steel bars to negate its weak tension carrying capacity. However, due to higher cost and non-renewability of steel, nowadays attempts were made to provide a low-cost, sustainable material. The feasibility for the usage of locally procured bamboo as reinforcement is tested to evaluate its Elasticity and ultimate strength. The axial compression test on various columns were performed comparing its axial deformation, Energy absorption capacity, ultimate load, displacement ductility and degradation in stiffness.
\end{abstract}

\section{KEYWORDS}

Bamboo Reinforcement, Compression Test, Split Tension, Column, Coconut Shell Aggregate, Different Length, Energy, Ductility, Stiffness

\section{INTRODUCTION}

Concrete is the most widely used material in building construction. The demand for concrete had increased in the last few decades. Among the entire constituent in concrete, aggregates form the major portion, which set off an increased demand for coarse aggregate. Coarse aggregate are generally the crushed natural stone which are non-renewable in nature. Further there exit a challenge in attaining the light weight concrete utilizing the waste. Structural light weight concrete should have a density less than $2000 \mathrm{~kg} / \mathrm{m}^{3}$ and compressive strength more than 20 $\mathrm{N} / \mathrm{mm}^{2}$ [1]. This is generally achieved by replacing the coarse aggregate with light weight aggregate.

Among the several wastes that are available around the world, coconut shells can suitably replace the natural aggregate in concrete. $[2,3]$ found that the coconut shell concrete can able to achieve its full strain capacity under shear loading. $[4,5]$ experimentally found that the bond strength of coconut shell concrete is much higher than the bond strength estimated by BS 8110 and IS 456:2000. A lot of research work has been carried out on the optimum replacement of coconut shell aggregate and has proved to be an appropriate replacement for coarse aggregate achieving the requirement for structural light weight concrete.

Concrete is very strong in compression but weak in tension. To overcome this concrete are reinforced with steel bars. However the use of steel as reinforcing material has several disadvantages like higher cost, non-renewability of steel and is responsible for the major emission 
of greenhouse gas. Several attempts were made by the researcher to provide a low-cost sustainable material. In this regards vegetable fibres were studied in the past which include jute [6, 7], coconut coir [8, 9], sisal [10], babadua [11], date palm [12], raffia palms [13], bamboo [14, 15] and bamboo fibres [16]. Although most of these studies yielded good result, bamboo is superior to other natural reinforcing materials.

Bamboo is a fast growing wood like material belongs to the grass family Poaceae. The tensile strength of bamboo is very high and for some species, its ultimate tensile strength is same as the yield strength of mild steel. The strength to specific weight ratio of bamboo is six times higher than that of the steel. Bamboo can take tension as well as compression load, whereas other vegetable reinforcing materials cannot carry compression loading. Furthermore, the energy required to produce one cubic meter per unit stress of bamboo is 50 times lower than the energy required by steel [17]. Due to these properties had attracted many researchers for using bamboo as reinforcement in concrete. Mansur et al., [18] experimentally evaluated the feasibility of using bamboo in the form of woven mesh as reinforcement in cement mortar. This study indicates that the inclusion of bamboo mesh imparts considerable ductility and toughness to the mortar, with significant increase in tensile, flexural and impact strength. Ghavami [14] experimentally found out that, the ultimate load carrying capacity of bamboo reinforced concrete is increased four times for bamboo reinforced concrete when compared with unreinforced concrete. Further, the author found that the bonding between bamboo and concrete is lower than that of steel and concrete which reduces its tension carrying capacity. Prasad et al., [19] used bamboo reinforced cementsand mortar panels for the construction of low cost housing in hilly region. Adom - Asmoah [20] recommends the usage of steel stirrups to improve its load carrying capacity.

No literature review is available replacing the coarse aggregate with coconut shell and steel with bamboo as reinforcement to obtain a integral structural light weight concrete with coconut shell as coarse aggregate and renewable bamboo as reinforcement. The axial compression test on steel reinforced concrete columns with conventional concrete, steel reinforced concrete columns with coconut shell concrete and bamboo reinforced concrete column with coconut shell concrete are performed to compare its axial deformation, ultimate load, energy dissipation capacity, displacement ductility and degradation in stiffness.

\section{Selection And Preparation Of Bamboo Strips}

The current research primarily aims at performing the axial load test on column replacing coconut shell as coarse aggregate and bamboo as reinforcement. The bamboo culm from the local market (SP-Dera) are procured considering the guidelines such as the samples procured are between 3 to 5 years of age, having a brownish appearance and samples which are been cut in winter season. Thereafter bamboo stripes of desired size are made from these bamboo culms using lathe machine.

\subsection{Moisture Content}

The optimum hours of oven drying (at $100^{\circ} \mathrm{C}$ ) is calculated on the samples to determine the percentage reduction in moisture content. Table 1 shows the initial weight of the bamboo specimens and the corresponding reduction in weight after 2hours, 4hours, 6hours and 8hours of testing. Figure 1 shows the average percentage reduction in moisture content for different hours of drying. 
From the above table it is been observed that beyond 6hours of oven drying, weight of the specimen remains the same. From Figure 1 it is been noticed that the graph follows a linear path beyond 6hours of oven drying. Hence the compression test and tension test were performed on 8hours of oven dried bamboo.

Table 1. Moisture test on bamboo specimen

\begin{tabular}{|c|c|c|c|c|c|}
\hline Description & \multicolumn{2}{|c|}{ Initial Weight } & \multicolumn{3}{|c|}{ Weight After 2 Hours of Drying } \\
\hline Sample No. & In $\mathrm{Kg}$ & In $\mathrm{N}$ & In $\mathrm{Kg}$ & $\begin{array}{c}\% \\
\text { Reduction }\end{array}$ & Average \\
\hline 1 & 0.13 & 1.2 & 0.11 & 11.0 & \multirow{3}{*}{10.8} \\
\hline 2 & 0.14 & 1.4 & 0.13 & 10.7 & \\
\hline 3 & 0.15 & 1.5 & 0.13 & 10.8 & \\
\hline Description & \multicolumn{2}{|c|}{ Initial Weight } & \multicolumn{3}{|c|}{ Weight After 4 Hours of Drying } \\
\hline Sample No. & In $\mathrm{Kg}$ & In $\mathrm{N}$ & In $\mathrm{Kg}$ & $\begin{array}{c}\% \\
\text { Reduction }\end{array}$ & Average \\
\hline 1 & 0.15 & 1.5 & 0.12 & 21.4 & \multirow{3}{*}{19.9} \\
\hline 2 & 0.19 & 1.8 & 0.15 & 19.1 & \\
\hline 3 & 0.18 & 1.8 & 0.15 & 19.3 & \\
\hline Description & \multicolumn{2}{|c|}{ Initial Weight } & \multicolumn{3}{|c|}{ Weight After 6 Hours of Drying } \\
\hline Sample No. & In $\mathrm{Kg}$ & In $\mathrm{N}$ & In $\mathrm{Kg}$ & $\begin{array}{c}\% \\
\text { Reduction }\end{array}$ & Average \\
\hline 1 & 0.15 & 1.4 & 0.09 & 28.7 & \multirow{3}{*}{27.8} \\
\hline 2 & 0.12 & 1.2 & 0.08 & 27.2 & \\
\hline 3 & 0.15 & 1.4 & 0.07 & 27.6 & \\
\hline Description & \multicolumn{2}{|c|}{ Initial Weight } & \multicolumn{3}{|c|}{ Weight After 8 Hours of Drying } \\
\hline Sample No. & In $\mathrm{Kg}$ & In $\mathrm{N}$ & In $\mathrm{Kg}$ & $\begin{array}{c}\% \\
\text { Reduction }\end{array}$ & Average \\
\hline 1 & 0.13 & 1.2 & 0.10 & 28.00 & \multirow{3}{*}{30} \\
\hline 2 & 0.12 & 1.1 & 0.08 & 31.00 & \\
\hline 3 & 0.10 & 1.1 & 0.10 & 31.00 & \\
\hline
\end{tabular}

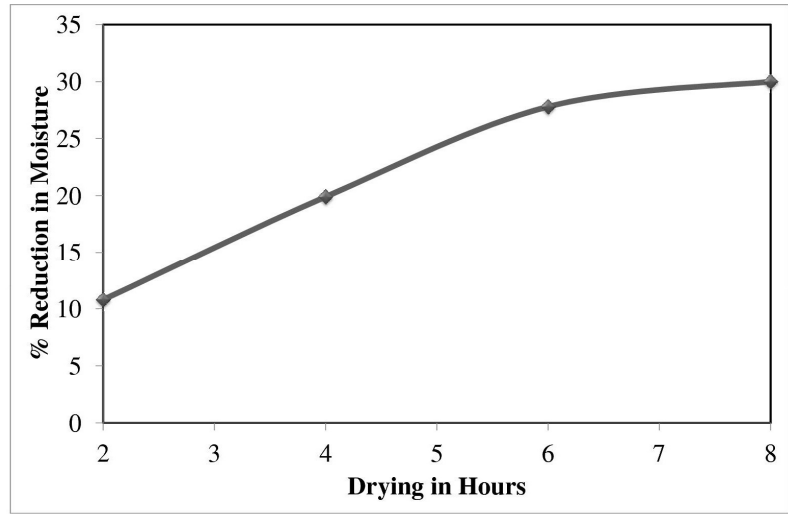

Figure 1. Average percentage reduction in moisture after oven drying 


\section{Experimental Program}

The test is conducted in a $2000 \mathrm{kN}$ compression testing machine (CTM). The load is applied gradually from zero up to failure. Figure 2 shows the compression test on bamboo specimen.

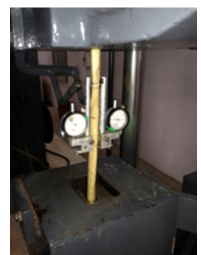

(a) Test Setup

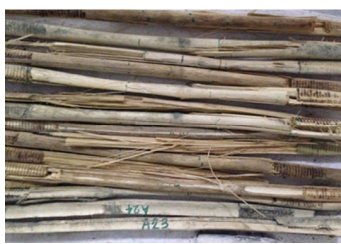

(b) Failure Pattern

Figure 2. Compression test on 8 hour of oven dried bamboo

The direct tension test is conducted in a 40 Ton universal testing machine (UTM). The load is applied gradually from zero. For each increment, the reading in extensometer is measured till failure. Figure 3 shows the direct tension test on bamboo.

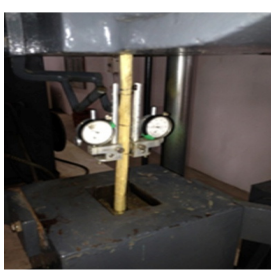

(a) Test setup

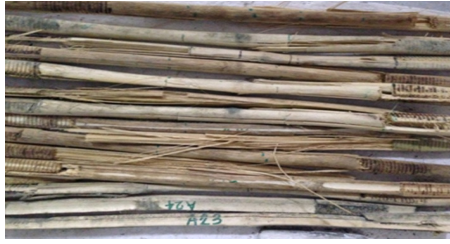

(b) Failure pattern

Figure 3. Direct tension test on 8 hour of oven dried bamboo

The current research primarily aims at performing the axial compression test on column replacing coconut shell as coarse aggregate. The concrete grade of M25 mix, designed as per Indian standards (IS 10262:2009) is used in this study to determine the compression strength of cube and split tensile strength of cylinder after 7 days, 14 days and 28 days. The Indian standard specifies (IS 456:2000) the characteristics compressive strength, Young's modulus and flexure strength are given by $25 \mathrm{~N} / \mathrm{mm}^{2}, 25000 \mathrm{~N} / \mathrm{mm}^{2}$ and $3.5 \mathrm{~N} / \mathrm{mm}^{2}$ respectively. The conventional concrete used for this study has a mix proportion of 1: 2.22: 3.66 and that of the coconut shell concrete [5] is 1: 1.47: 0.65. Figure 4 shows the compression test on cube and Figure 5 shows the split tensile testing on cylinder.

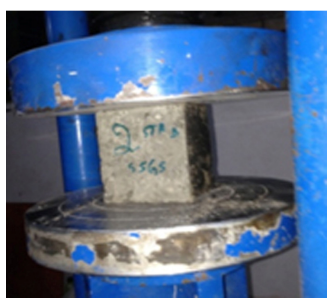

Figure 4. Compression testing on cube 
Bamboo is cut into 4 parts diameter wise along length and was made as a reinforcement of diameter $12 \mathrm{~mm}$. An epoxy resin was applied over the bamboo and is allowed to dry. The bamboo was tied with binding wire with $2.54 \mathrm{~cm}$ thread and made as reinforcement. The scope of the work involves, studying the behaviour on square column with $120 \mathrm{~mm}$ cross section of varying height. Three columns was casted for each arrangement (conventional concrete with steel reinforcement referred as "Type A", coconut shell concrete with steel reinforcement referred as "Type B" and coconut shell concrete with treated bamboo reinforcement referred as "Type C"). These specimens are de-moulded after 24 hours and then they are cured in water for 28 days. Axial compression test is performed on steel and bamboo reinforced columns of height $1000 \mathrm{~mm}$ and $1300 \mathrm{~mm}$. The loading frame with $40 \mathrm{~T}$ capacity is used to perform the compression test. The prepared specimen was erected in the loading frame to simulate the hinged condition. To the top plate proving ring was attached to measure the load. The compression test set up is shown in Figure 6. The load is applied axially in a step of $1000 \mathrm{~N}$ and for each load step; the axial compression by means of dial gauge were taken, till the column could resist the load.
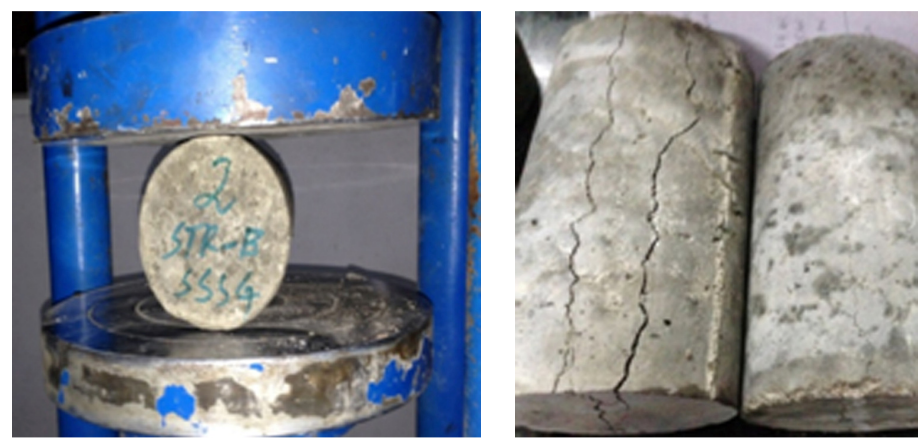

Figure 5. Split tensile strength of cylinder

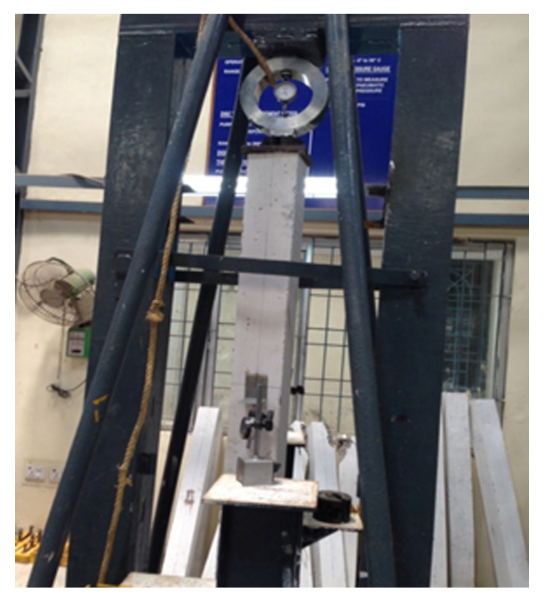

Figure 6. Loading frame for testing the column 


\section{RESUlt AND DisCuSSION}

The results of the tests conducted on the bamboo strips and on the column specimen elements described in Section 2 are presented in this section. Based on these results relevant discussions are provided.

\subsection{Compression And Tension Testing On Bamboo}

Compression and tensile test is conducted on the locally procured bamboo strips to determine the ultimate strength and elasticity parameters of the bamboo as reinforcement. Few specimens are tested for this purpose. From Table 2 and Table 3 the average compressive and tensile strength is calculated as $48.16 \mathrm{~N} / \mathrm{mm}^{2}$ and $94.45 \mathrm{~N} / \mathrm{mm}^{2}$ respectively.

Table 2. Compression test on bamboo after 8 hour of oven drying

\begin{tabular}{|c|c|c|c|c|c|}
\hline Trail & $\begin{array}{l}\text { Load in kN } \\
\text { (P) }\end{array}$ & $\begin{array}{l}\text { Dimension of } \\
\text { bamboo in } \\
\mathrm{mm}\end{array}$ & $\begin{array}{c}\text { Area in } \\
\mathrm{mm}^{2} \\
(\mathrm{~A})\end{array}$ & $\begin{array}{c}\text { Compressive } \\
\text { stress in } \\
\mathrm{N} / \mathrm{mm}^{2} \\
(\mathrm{P} / \mathrm{A})\end{array}$ & $\begin{array}{c}\text { Average } \\
\text { compressive } \\
\text { stress in } \\
\mathrm{N} / \mathrm{mm}^{2}\end{array}$ \\
\hline 1 & 65 & \multirow[t]{3}{*}{ - $\begin{array}{l}60 \\
40\end{array}$ - } & \multirow{3}{*}{1570} & 41.40 & \multirow{3}{*}{48.16} \\
\hline 2 & 67 & & & 42.60 & \\
\hline 3 & 95 & & & 60.5 & \\
\hline
\end{tabular}

The direct tensile test is conducted on the bamboo to determine the modulus of elasticity. Table 4, shows the direct tensile test on bamboo and the corresponding Figure 7 shows the stress - strain graph for bamboo specimen after 8 hours of oven drying. The modulus of elasticity of bamboo is $25700 \mathrm{~N} / \mathrm{mm}^{2}$.

Table 3. Result for direct tension test on bamboo after 8 hour of oven drying

\begin{tabular}{|c|c|c|c|c|c|l|}
\hline \multirow{4}{*}{ Trial } & $\begin{array}{c}\text { Diameter } \\
\text { of } \\
\text { specimen } \\
\text { in } \mathrm{mm}\end{array}$ & $\begin{array}{c}\text { Area } \\
\text { in } \\
\mathrm{mm}^{2}\end{array}$ & $\begin{array}{c}\text { Load in } \\
\mathrm{N}\end{array}$ & $\begin{array}{c}\text { Tensile } \\
\text { stress in }\end{array}$ & $\begin{array}{c}\text { Average } \\
\text { tensile } \\
\text { stress in }\end{array}$ & Type of failure \\
& $\mathrm{N} / \mathrm{mm}^{2}$ & $\mathrm{P} / \mathrm{A}$ & $\mathrm{N} / \mathrm{mm}^{2}$ & \\
\hline 1 & $\mathrm{D}=9.16$ & 66.47 & 6082.2 & 91.50 & 94.45 & Splitting failure \\
\hline
\end{tabular}

Table 4. Direct tension test on bamboo after 8 hour of oven drying

\begin{tabular}{|c|c|c|c|c|c|c|}
\hline $\begin{array}{l}\text { Load in } \\
\mathrm{N} \\
\text { (P) }\end{array}$ & $\begin{array}{c}\text { Diameter of } \\
\text { specimen in } \\
\mathrm{mm}\end{array}$ & $\begin{array}{c}\text { Area in } \\
\mathrm{mm}^{2} \\
(\mathrm{~A})\end{array}$ & $\begin{array}{c}\text { Stress in } \\
\mathrm{N} / \mathrm{mm}^{2} \\
(\mathrm{P} / \mathrm{A})\end{array}$ & $\begin{array}{l}\text { Extensometer } \\
\text { reading in } \mathrm{mm}\end{array}$ & $\begin{array}{l}\text { Strain } \\
\times 10^{-4}\end{array}$ & $\begin{array}{l}\text { Modulus of } \\
\text { elasticity in } \\
\mathrm{N} / \mathrm{mm}^{2}\end{array}$ \\
\hline 981 & \multirow{6}{*}{$\mathrm{D}=9.2$} & \multirow{6}{*}{66.47} & 15.42 & 0.06 & 6 & \multirow{6}{*}{$2.57 \times 10^{4}$} \\
\hline 1962 & & & 30.84 & 0.13 & 13 & \\
\hline 2943 & & & 46.24 & 0.21 & 21 & \\
\hline 3924 & & & 61.68 & 0.29 & 29 & \\
\hline 4905 & & & 77.10 & 0.35 & 35 & \\
\hline 5886 & & & 92.52 & 0.44 & 44 & \\
\hline
\end{tabular}


Civil Engineering and Urban Planning: An International Journal(CiVEJ) Vol.3,No.1, March 2016

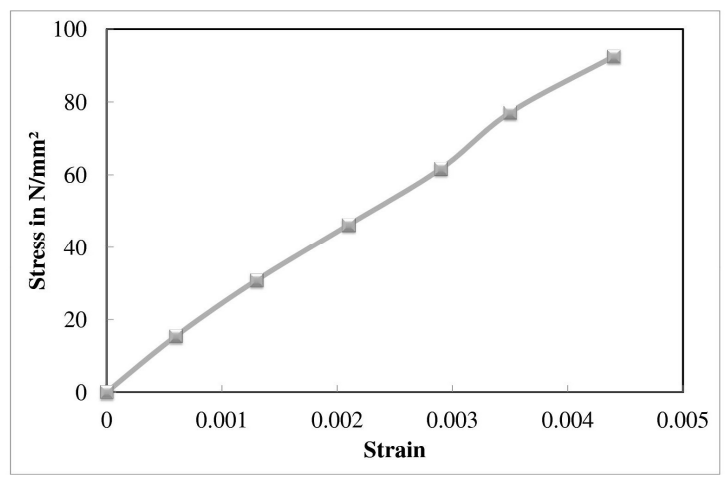

Figure 7. Stress - strain curve for bamboo after 8 hour of oven drying

\subsection{Compression And Split Tension Testing On Concrete}

Compression and split tensile test is conducted on the conventional and coconut shell concrete after 7 days, 14 days and 28 days of curing.

Table 5. Compressive strength on cube

\begin{tabular}{|l|c|c|c|}
\hline \multirow{2}{*}{ Description } & \multicolumn{3}{|c|}{ Compression strength in N/mm ${ }^{2}$} \\
\cline { 2 - 4 } & \multicolumn{3}{|c|}{ Days of curing } \\
\cline { 2 - 4 } & 7 Days & 14 Days & 28 Days \\
\hline Conventional concrete & 21.1 & 25.53 & 28.2 \\
\hline Coconut shell concrete & 18.8 & 23.9 & 26.4 \\
\hline
\end{tabular}

Table 5 shows the compression strength of cube. Conventional concrete attained the compression strength of $25 \mathrm{~N} / \mathrm{mm}^{2}$ after 14 days of curing where as coconut shell concrete attains the estimated strength after 28 days of curing. Table 6 shows the corresponding split tensile strength of the specimen. After 28 days of curing split tensile strength is almost the same for conventional and coconut shell concrete.

Table 6. Split tensile strength on cylinder

\begin{tabular}{|c|c|c|c|}
\hline \multirow{2}{*}{ Description } & \multicolumn{3}{|c|}{ Split tensile strength in N/mm ${ }^{2}$} \\
\cline { 2 - 4 } & \multicolumn{3}{|c|}{ Days of curing } \\
\cline { 2 - 4 } & 7 Days & 14 Days & 28 Days \\
\hline Conventional concrete & 1.43 & 2.74 & 2.86 \\
\hline Coconut shell concrete & 1.12 & 2.49 & 2.62 \\
\hline
\end{tabular}

Compression and tensile test is conducted on the locally procured bamboo strips to determine the ultimate strength and elasticity parameters of the bamboo as reinforcement. Few specimens are tested for this purpose. From Table 2 and Table 3 the average compressive and tensile strength is calculated as $48.16 \mathrm{~N} / \mathrm{mm}^{2}$ and $94.45 \mathrm{~N} / \mathrm{mm}^{2}$ respectively.

The direct tensile test is conducted on the bamboo to determine the modulus of elasticity. Table 4, shows the direct tensile test on bamboo and the corresponding Figure 7 shows the stress - strain graph for bamboo specimen after 8 hours of oven drying. The modulus of elasticity of bamboo is $25700 \mathrm{~N} / \mathrm{mm}^{2}$. 


\subsection{Testing On Column}

Axial compression test is performed on steel and bamboo reinforced columns of two different length. Totally 18 columns were casted which includes 6 numbers of reinforced concrete columns with conventional concrete, 6 numbers of steel reinforced concrete columns with coconut shell concrete and 6 numbers of bamboo reinforced concrete column with coconut shell concrete. The load - deformation behaviour of columns under axial compression are shown in Figure 8 and Figure 9 for $1 \mathrm{~m}$ and $1.3 \mathrm{~m}$ respectively. It is observed from this figures that, the area under the load-deformation curves for Type A is more than that of the Type B and Type $\mathrm{C}$ which indicates that the Type A has the high energy absorption capacity, which is evident from the Table 7 and Table 8.

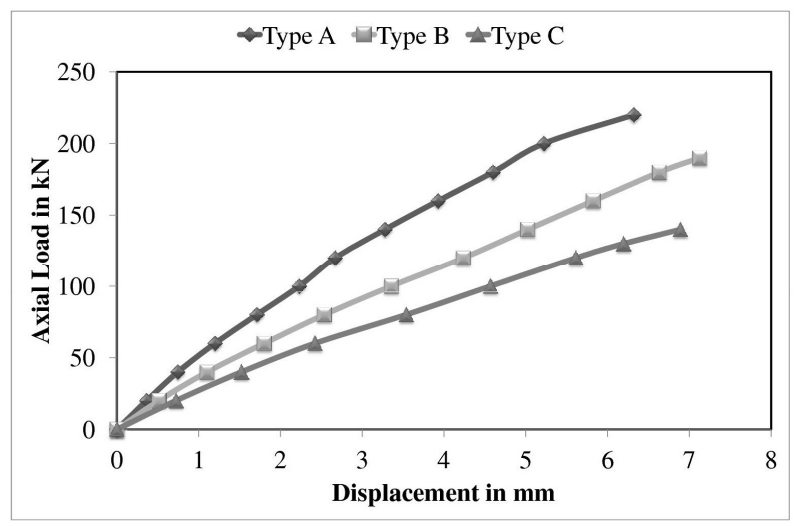

Figure 8. Load - deflection curve for 1m column under axial compression

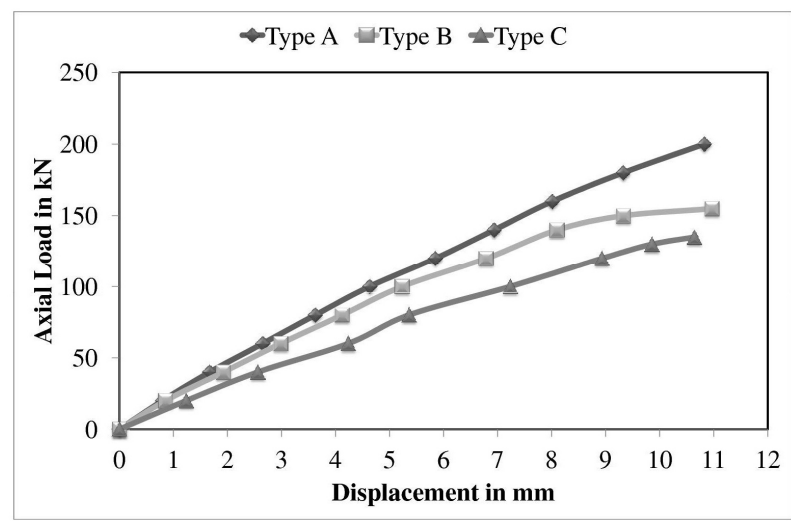

Figure 9. Load - deflection curve for $1.3 \mathrm{~m}$ column under axial compression

Table 7. Energy absorption for $1 \mathrm{~m}$ column

\begin{tabular}{|c|c|c|}
\hline \multicolumn{3}{|c|}{ Energy $(\mathrm{J})$} \\
\hline Type A & $\mathrm{E}_{\mathrm{A}}$ & 815.7 \\
\hline Type B & $\mathrm{E}_{\mathrm{B}}$ & 735.2 \\
\hline Type C & $\mathrm{E}_{\mathrm{C}}$ & 530.3 \\
\hline
\end{tabular}


Table 8 . Energy absorption for $1.3 \mathrm{~m}$ column

\begin{tabular}{|c|c|c|}
\hline \multicolumn{3}{|c|}{ Energy $(\mathrm{J})$} \\
\hline Type A & $\mathrm{E}_{\mathrm{A}}$ & 1210.6 \\
\hline Type B & $\mathrm{E}_{\mathrm{B}}$ & 1114.4 \\
\hline Type C & $\mathrm{E}_{\mathrm{C}}$ & 849.9 \\
\hline
\end{tabular}

From above table for each case it is observed that as the height of the column increases energy absorption capacity increases. From Table 7 it is evident that, energy absorption capacity of Type $\mathrm{B}$ and Type $\mathrm{C}$ is $90 \%$ and $65 \%$ of Type A whereas, from Table 8 it is clear that irrespective of change in height, almost a similar variation is been observed (92\% and 70\%). From Figure 8 and Figure 9 it is noticeable that the ultimate deformation of Type B column is higher that Type A and Type $\mathrm{C}$ which is evident from the Table 9 and Table 11.

Table 9. Comparison of ultimate displacement of $1 \mathrm{~m}$ column

\begin{tabular}{|c|c|c|c|c|}
\hline \multicolumn{4}{|c|}{$1 \mathrm{~m}$ Column } & \multirow{2}{*}{ Remark } \\
\hline \multicolumn{3}{|c|}{ Displacement (Type A) in mm } & 6.321 & \\
\hline Type B & 7.125 & \% Variation w.r.t Type A & 13 & Increase \\
\hline Type C & 6.89 & \% Variation w.r.t Type A & 9 & Increase \\
\hline
\end{tabular}

From above table Type B and Type C column has a variation of $13 \%$ and $9 \%$ however due to decrease in yield deformation the displacement ductility of Type A is higher when compared with other arrangement. From Table 10 it is observed that the displacement ductility of Type A and Type B column is $82 \%$ and $42 \%$ higher, when compared with that of Type C column.

Irrespective of variation in height the ultimate deformation of Type B column is higher that Type $\mathrm{A}$ and Type $\mathrm{C}$ which is evident from the Table 11. From Table 11 it is observed that the displacement increases by $1 \%$ for Type B column and decreases by $2 \%$ Type $\mathrm{C}$ column however due to decrease in yield deformation the displacement ductility of Type A is higher when compared with other arrangement.

Table 10. Comparison in displacement ductility of $1 \mathrm{~m}$ column

\begin{tabular}{|c|c|c|}
\hline \multirow{2}{*}{ Type of Specimen } & \multicolumn{2}{|c|}{ Ductility } \\
\cline { 2 - 3 } & \multicolumn{2}{|c|}{$1 \mathrm{~m}$} \\
\hline Type A & 17.37 & 1.82 \\
\hline Type B & 13.89 & 1.46 \\
\hline Type C & 9.53 & 1.00 \\
\hline
\end{tabular}

Table 11. Comparison of ultimate displacement of $1.3 \mathrm{~m}$ column

\begin{tabular}{|c|c|c|c|c|}
\hline \multicolumn{4}{|c|}{$1.3 \mathrm{~m}$ Column } & \multirow{2}{*}{ Remark } \\
\hline & Displ & $\mathrm{t}$ (Type A) in $\mathrm{mm}$ & 10.826 & \\
\hline Type B & 10.97 & \% Variation w.r.t Type A & 1 & Increase \\
\hline Type C & 10.642 & \% Variation w.r.t Type A & 2 & Decrease \\
\hline
\end{tabular}

From Table 12 it is observed that there is a vast variation in displacement ductility of Type A and Type B column when compared with that of Type C column. 
Civil Engineering and Urban Planning: An International Journal(CiVEJ) Vol.3,No.1, March 2016

Table 12. Comparison in displacement ductility of $1.3 \mathrm{~m}$ column

\begin{tabular}{|c|c|c|}
\hline \multirow{2}{*}{$\begin{array}{c}\text { Type of } \\
\text { Specimen }\end{array}$} & \multicolumn{2}{|c|}{ Ductility } \\
\cline { 2 - 3 } & \multicolumn{2}{|c|}{$1.3 \mathrm{~m}$} \\
\hline Type A & 13.58 & 3.27 \\
\hline Type B & 12.87 & 3.10 \\
\hline Type C & 4.15 & 1.00 \\
\hline
\end{tabular}

Figure 10 and Figure 11 shows the degradation of stiffness by plotting a graph between $\mathrm{P} / \mathrm{P}_{\mathrm{U}}-$ Stiffness for $1 \mathrm{~m}$ and $1.3 \mathrm{~m}$ respectively. The variation in stiffness between the initial and ultimate load for $1 \mathrm{~m}$ and $1.3 \mathrm{~m}$ is shown in the corresponding Table 13. It is been evident that the percentage degradation in stiffness of Type $\mathrm{C}$ is less than Type $\mathrm{A}$ and Type $\mathrm{B}$ column, which is authenticated from the non-dimensional graph (Figure 12 and Figure 13) from which it is apparent that the slope of Type $\mathrm{C}$ is lesser than Type $\mathrm{A}$ and Type B column which marks the lowest degradation in stiffness.

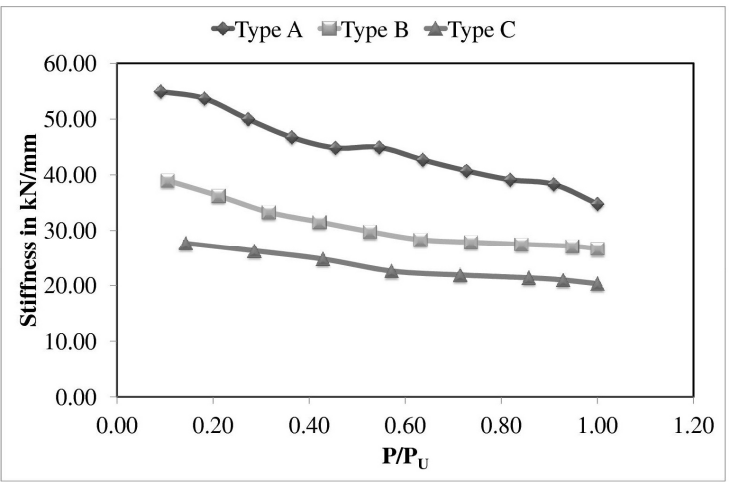

Figure 10. $\mathrm{P} / \mathrm{P}_{\mathrm{U}}$ Vs Stiffness for $1 \mathrm{~m}$ Length of Column

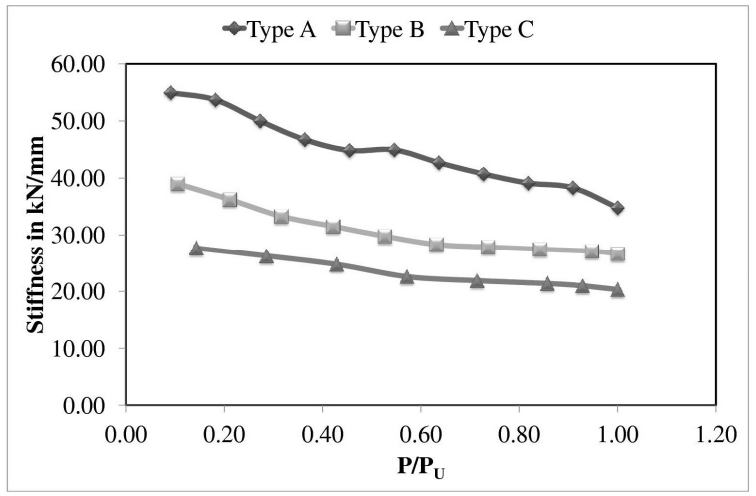

Figure 11. $\mathrm{P} / \mathrm{P}_{\mathrm{U}}$ Vs Stiffness for $1.3 \mathrm{~m}$ Length of Column 
Civil Engineering and Urban Planning: An International Journal(CiVEJ) Vol.3,No.1, March 2016

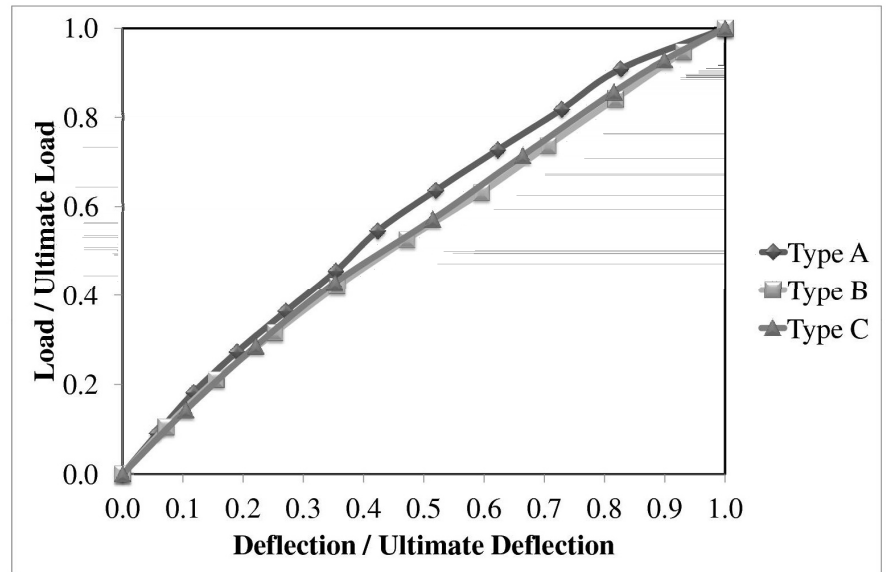

Figure 12. Non-Dimensional Graphs for Columns of $1 \mathrm{~m}$ Length

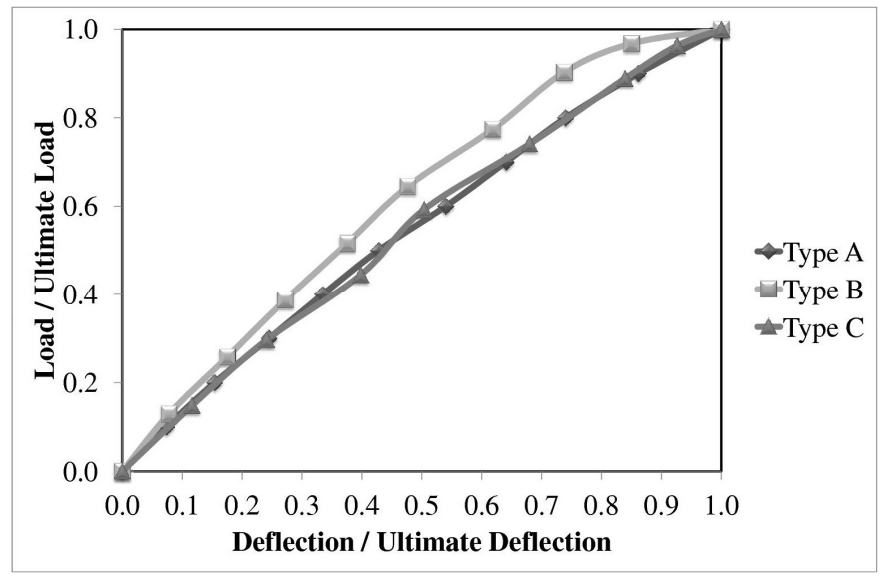

Figure 13. Non-Dimensional Graphs for Columns of 1.3m Length

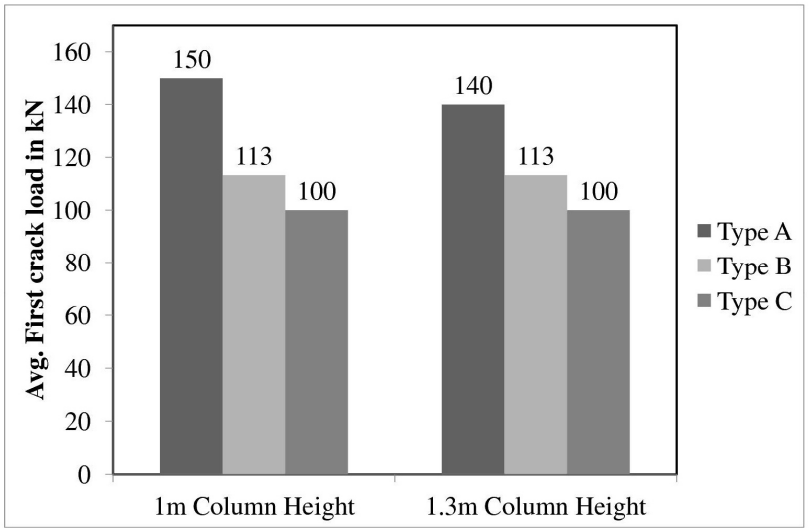

Figure 14. Average Value of First Crack Load 


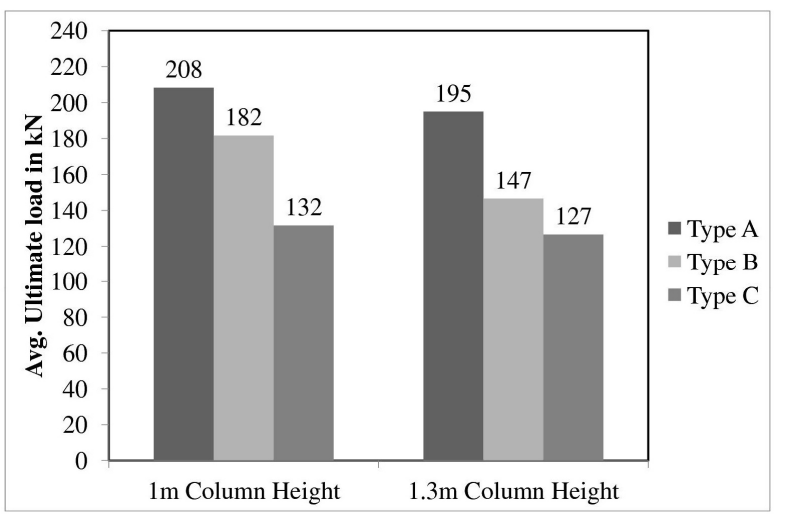

Figure 15. Average Value of Ultimate Crack Load

Table 13. Comparison of Degradation in Stiffness

\begin{tabular}{|c|c|c|c|}
\hline \multicolumn{4}{|c|}{$1 \mathrm{~m}$ Column } \\
\hline \multirow{2}{*}{ Type } & \multicolumn{2}{|c|}{ Stiffness $\mathrm{kN} / \mathrm{mm}$} & \multirow{2}{*}{$\%$ Degradation in Stiffness } \\
\hline & Initial & Ultimate load & \\
\hline$\overline{\mathrm{A}}$ & 54.95 & 34.80 & 36.66 \\
\hline $\mathrm{B}$ & 38.99 & 26.67 & 31.60 \\
\hline $\mathrm{C}$ & 27.66 & 20.32 & 26.55 \\
\hline \multicolumn{4}{|c|}{$1.3 \mathrm{~m}$ Column } \\
\hline Type & \multicolumn{2}{|c|}{ Stiffness kN/mm } & $\%$ Degradation in Stiffness \\
\hline & Initial & Ultimate load & \\
\hline$\overline{\mathrm{A}}$ & 25.09 & 18.47 & 26.38 \\
\hline B & 23.47 & 14.13 & 39.79 \\
\hline $\mathrm{C}$ & 16.18 & 12.69 & 21.60 \\
\hline
\end{tabular}

The average value of first crack load and ultimate load for different arrangement of column is shown in the corresponding Figure 14 and 15. It is observed that the first crack load for corresponding to Type B and Type C column remains same irrespective of change in height. From Figure 15 it is observed that the ultimate crack load of Type $C$ column remains same irrespective of change in height.

\section{Conclusions}

In this study the prospect of utilization of bamboo and coconut shell as a replacement for reinforcement and aggregate has been evaluated through a series of experimental investigations on 18 columns, which includes 6 numbers of steel reinforced concrete columns with conventional concrete (Type A), 6 numbers of steel reinforced concrete columns with coconut shell concrete (Type B) and 6 numbers of bamboo reinforced concrete column with coconut shell concrete (Type C). The tests performed in the due course of this research include moisture test on bamboo, compression and tensile test of bamboo specimen to estimate the Young's Modulus. Further compression and split tensile test were performed for conventional concrete and coconut shell concrete finally the axial load test on columns were carried out. The conclusion drawn from the axial test on column were summarised below: 
1. Energy absorption capacity enhance with increase in height of column, further the energy absorption capacity of Type A column is higher than other configuration

2. Ultimate displacement of Type B column is superior when compared with Type A and Type $\mathrm{C}$ configuration

3. With decrease in yield deformation the displacement ductility of Type A column is superior to other configuration

4. Degradation in stiffness of Type $\mathrm{C}$ column is the least among its configuration which marks an lesser slope in non dimensional graph for Type $\mathrm{C}$ column

5. Irrespective of change in height the average value of first crack load in Type B and Type $\mathrm{C}$ column remain the same. Whereas the average ultimate load in Type $\mathrm{C}$ column remains identical

\section{REFERENCES}

[1] AhsanSabbir, Md., and Ashfaqul, S. M., (2001) "Determination of Tensile Property of Bamboo for Using as Potential Reinforcement in the Concrete", IJCEE-IJENS Vol: 11 pp05

[2] Gunasekaran, K., (2011) "Long term study on compressive and bond strength of coconut shell aggregate concrete", vol. 3, pp 208-215.

[3] Gunasekaran, K., and Kumar, P. S., (2008) "Lightweight concrete using coconut shell as aggregate", In Proceedings of the ICACC-2008, International conference on advances in concrete and construction, Hyderabad, India, 7-9 February, pp 450-9.

[4] Gunasekaran, K., Kumar, P. S., and Lakshmipathy, M., (2011) "Mechanical and bond properties of coconut shell concrete", Construction Building Material, 25(1), pp 92-8.

[5] Gunasekaran, K., Kumar, P. S., and Lakshmipathy, M., (2011) "Mechanical and bond properties of coconut shell concrete", Construction Building Material, 25(1), pp 92-8.

[6] Mansur, M. A., and Aziz, M. A., (1982) "A study of jute fibre reinforced cement composites", International Journal Cement Composite Lightweight Concrete, 4(2), pp 75-82.

[7] Chakraborty, S., Kundu, S. P., Roy, A., Adhikari, B., and Majumder, S. B., (2013) "Polymer modified jute fibre as reinforcing agent controlling the physical and mechanical characteristics of cement mortar", Construction Building Material, 49(2), pp 14-22.

[8] Islam, S.M., Hussain, R. R., and Morshed, M. A. Z., (2012) "Fiber-reinforced concrete incorporating locally available natural fibers in normal-and high-strength concrete and a performance analysis with steel fiber-reinforced composite concrete", Journal Composite Material, Vol 46(1), pp 111-22.

[9] Ali, M., Liu, A., Sou, H., and Chouw, N., (2012) "Mechanical and dynamic properties of coconut fibre reinforced concrete", Construction Building Material, Vol 30(8), pp 14-25.

[10] Filho, T., Dias, R., Silva, F. D. A., and Fairbairn, E. M. R., (2009) "Durability of compression molded sisal fiber reinforced mortar laminates", Construction Building Material, Vol. 23(6), pp 2409-20.

[11] Kankam, C. K., and Odum-Ewuakye, B., (2006) "Babadua reinforced concrete two-way slabs subjected to concentrated loading”, Construction Building Material, Vol. 20(5), pp 279-85.

[12] Kriker, A., Debicki, G., Bali, A., Khenfer, M. M., and Chabannet, M., (2005) "Mechanical properties of date palm fibres and concrete reinforced with date palm fibres in hot-dry climate", Cement Concrete Composite, Vol. 27(5), pp 554-64.

[13] Kankam, C. K., (1997) "Raffia palm-reinforced concrete beams", Material Structure, Vol. 30(5), pp 313-6.

[14] Ghavami, K., (1995) "Ultimate load behaviour of bamboo-reinforced lightweight concrete beams", Cement Concrete Composite, Vol. 17(4), pp 281-8.

[15] Rahman, M. M., Rashid, M. H., Hossain, M. A., Hasan, M. T., and Hasan, M. K., (2011) "Performance evaluation of bamboo reinforced concrete beam", International Journal of Engineering Technology, Vol. 11(4), pp 142-6.

[16] Ramaswamy, H. S., Ahuja, B. M., and Krishnamoorthy, S., (1983) "Behaviour of concrete reinforced with jute, coir and bamboo fibres", International Journal of Cement Composite Lightweight Concrete, Vol. 5(1), pp 3-13.

[17] Ghavami, K., (2005), "Bamboo as reinforcement in structural concrete elements", Cement Concrete Composite, Vol. 27(6), pp 637-49.

[18] Mansur, M. A., and Aziz, M. A., (1983) "Study of bamboo mesh reinforced cement composites", International Journal of Cement Composite Lightweight Concrete, Vol. 5(3), pp 165-71. 
Civil Engineering and Urban Planning: An International Journal(CiVEJ) Vol.3,No.1, March 2016

[19] Prasad, J., Pandey, B. S., Ahuja, R., and Ahuja, A. K., (2005) "Low cost housing for hilly regions using locally available material", Asian Journal of Civil Engineering Building Housing, Vol. 6(4), pp 257-65.

[20] Adom-Asamoah., (2010), "A comparative study of Bamboo reinforced concrete beams using different stirrup materials for rural construction”, International journal of civil and structural engineering, Vol. 